PAULA C. LOWE

\title{
THE PERPETUAL MELANCHOLY OF PAULINE LARSON
}

Slayton, Minnesota, 1945

On the flat palm of prairie, you were born to wail in a muffling dark of broken sod and barn stones cobbled from the land like potatoes peeled with a knife into a white tin basin.

You were a blue girl inside a ring of desperate trees circled with their backs to the northwest wind, a daughter darning socks by a brother whittling sticks while a blizzard drift-locked your doors.

Pauline, how did you carry on in that county of perpetual melancholy, wear wool washed in muddy water pailed from Beaver Creek, wear stains of silt that wouldn't beat out even as you stretched your skirts over chokecherry?

Busted banks and world wars took and broke men and sent them back to fields and streets of Hadley with no wheat to feed them.

How did you lift despair in your hands and learn to drink its tea? Marry a road maker back from the trenches, bring up babies in a caboose at the back of his mule caravan? 
How did you raise your only boy to let ships make him

a man, dress him in sailor whites

washed in bleach to blur

his fear sweat?

And more war? And then war in your chest, a knife in your breast.

How did you roast your last Easter meal, carry high

a platter of ham in your swollen arms

to your son come home in uniform?

How did you live that long? 